\title{
Towards the Circular Economy: Waste Contracting
}

Henning Wilts* and Alexandra Palzkill

Wuppertal Institute for Climate, Environment and Energy, Germany

*Corresponding author: Henning Wilts, Wuppertal Institute for Climate, Environment and Energy, Germany, Tel. +49-202-2492-290; Fax: +49-202-2492-138; E-mail: henning.wilts@wupperinst.org

Received date: January 16, 2015, Accepted date: March 13, 2015, Published date: March 18, 2015

Copyright: (c) 2015 Wilts $\mathrm{H}$, et al. This is an open-access article distributed under the terms of the Creative Commons Attribution License, which permits unrestricted use, distribution, and reproduction in any medium, provided the original author and source are credited.

\begin{abstract}
The transition towards a circular economy is high on the political agenda and support for innovative business models can be seen as one of the key strategies for its implementation. Nevertheless most of these business models rely on an increasing generation of waste and thus undermine the prevention of waste as top of the waste hierarchy. The paper aims to link this debate to more systemic eco-innovations that offer economic market potentials by reduced material inputs and waste generation. This directs the attention to sufficiency strategies that surpass the level of individual consumer choices and regards the potentials of entrepreneurial sufficiency strategies. It takes the example of waste contracting modelsin Germany as a possible approach of resource-light business models that provide existing utility aspects with altered consumption patterns and decreased resource consumption. It describes environmental and economic benefits and draws conclusions on necessary policy framework conditions.
\end{abstract}

Keywords: Circular economy; Waste prevention; Contracting; Innovative business models

\section{Introduction}

Strategies for the decoupling of consumption patterns, waste generation and related environmental burdens predominantly focus on technical efficiency and consistency. The overall aim is to reduce the use of resources with the help of technological progress and closed material cycles. Besides, so-called sufficiency strategies are described in the literature, which not only aim at a relative decrease of resource consumption, but by means of strategies of "less, slower" or "more regional" also aspire to achieve an absolute reduction in resource use and consequently waste generation. However, sufficiency strategies, if even discussed, mostly consider individual consumer choices [1-4] Especially in the face of the further increasing global resource consumption [5], this is an astonishing fact and directs the attention to sufficiency strategies that surpass the level of individual consumer choices and regards the potentials of entrepreneurial sufficiency strategies.

A common argument for the inadequacy of simple, usually technically dominated strategies is the so-called 'rebound effect' [6-8], which implies that successfully improved efficiency can lead to increased consumption, which again exhausts a part of the achieved savings - in unfavourable cases even overcompensates them. In terms of the rebound effect, very diverse causes can be found. Regarding direct cost savings in households, magnitudes of 10-30 \% are specified, while for indirect, macroeconomic effects only few, strongly varying sources are available, which, however, identify rebound effects of up to $100 \%$ [9]. On the other hand, the complete and equivalent substitution of all current goods and services in a "consistent" manner in terms of an environmentally sound resource use (e.g. through cradle to cradle approaches) is not foreseeable at this point in time - especially not under consideration of widely differing spatial and temporal problem shifts [5]. Therefore, hoping for the necessary technological leaps through market incentives is highly risky: "For all these reasons, consistency is indispensable - but alone not sufficient for the actuation of a sustainable development" [10-11].

Against this background this paper analyses innovative contracting business models in the field of waste management based on waste fee savings from waste prevention and improved waste separation in Germany. It aims to give new insights regarding how the overall concept of sufficiency could enrich discussions about a circular economy, how contracting can create new business opportunities in the waste sector and which policy instruments might increase the market uptake of such promising innovations. The paper is structured as follows: Chapter 2 describes the analytical framework and the methodology of the analysis, chapter 3 introduces the empirical foundation of the paper. Based on this theoretical and empirical basis, the final chapter draws conclusions on key success factors, the necessary political framework and further research.

\section{Theoretical Background}

\section{Key terms and definitions}

The term of sufficiency is defined in different ways in the literature. The following takes on a definition of Fischer et al.: "The term ,sufficiency' refers to changes in consumption patterns which facilitate operation within the ecological bearing capacity of the earth, whereby utility aspects of consumption are changing". Hence, it is clearly distinguished from efficiency and consistency: "for these two strategies assume that with a lower environmental consumption, benefits do not change: Efficiency quantitatively reduces resource inputs or emission outputs in proportion to the generation of the same benefits; while consistency achieves the same through another technology which is equally environmentally sound on a large scale. Sufficiency, however, is accompanied by modifications of the benefit package" [9]. Assessment thereby in each case takes place based on individual preferences: On the one hand, sufficiency is therefore often outlined as "renunciation" or "lower welfare" [12]. On the other hand, terms like the "succeeding life" or the "right measure" $[10,13]$ suggest that 
sufficiency could also bring forth an individual benefit - for example "time prosperity" [13], "freedom from excess" [14] or "the good life" [15]. This perception also addresses fundamental criticism brought for e.g. by Huber [16] who points out the often strongly paternalistic underlying assumptions of sufficiency policies.

For this paper we applied an analytical framework developed by Sachs [17] that distinguishes four fundamental sufficiency strategies (the so-called 4 D's) that oftentimes correspond with modified satisfaction of such benefit packages:

1. Decluttering (in terms of absolute reduction of the number and diversity of consumed/acquired products),

2. Deceleration (in terms of a reduction of the frequency of consumption),

3. Decommercialisation (in terms of the subsistence economy of DIY and production instead of commodification) and

4. Deconcentration (in terms of a simplification and regionalization of value chains).

\section{Sufficiency as Consequence of Innovative Business Strategies}

Despite its potential for resource conservation and the now recognized necessity of subsistence strategies for the reduction of global resource consumption, aside from individual consumer choices only few scientific approaches deal with the question and promotion of sufficiency strategies (on a political and/or entrepreneurial level) (first approaches to sufficiency policy see: $[9,15]$; on entrepreneurial sufficiency strategies [18-21]. Especially for business strategies targeted on sufficiency, which provide existing utility aspects with altered consumption patterns and decreased resource consumption, there is a considerable conceptional and instrumental deficit [22]. A deepening of implications specific to the company is therefore also hard to find, due to missing alternative conceptional landmarks. According to Paech, "new management concepts" [18] are in demand, which allow for a substitution or modification of existing consumer demands and develop new business models accordingly.

Along the abovementioned heuristics of the 4 D's, business models are indeed identifiable within which sufficiency becomes driver for a business case, or which take on trends towards sufficient behaviour $[9,22]$ including the provision of services instead of resource intensive goods (e.g. Carsharing); satisfaction of needs in the sense of "less is more" (simplify your life) (decluttering) or the establishment of offers that enable a longer use phase (e.g. cheap repair and replaceable batteries in laptops) (deceleration).

The following case study will apply this analytical framework to a specific case study - waste contracting in different German metropolitan regions. For the research several expert interviews have been conducted and public available as well as internal planning documents have been analyzed.

\section{Contracting}

\section{Contracting as contribution to resource efficiency}

A possible approach of such resource-light business models that provide existing utility aspects with altered consumption patterns and decreased resource consumption are contracting models, which have predominantly been developed in the energy sector up to now: They belong to the few business models which turn a "less" into an established business case. Performance contracting in the energy sector is a contractually agreed service between the owners of buildings and tenants on the one side and specialised energy service enterprises, the contractors, on the other side. The contractors optimize energy supply, mostly through a mixture of classical and technological efficiency measures, but also energy use by means of sufficiency measures and profits from saved energy costs over an extended contract term.

The benefits of contracting can include, next to cost savings, the involvement of external experts in the modernisation of infrastructures, the avoidance of short-term high investment costs for optimized infrastructures for the owner as well as the transfer of investment risks to the contractor and the reduction of liability risks, among others: "The actual advantage of contracting is, however, that the technical expertise of the contractor can be used for planning, construction and operation of structural and supply and control technical measures and the risk and possibly the financing can be transferred to him". So far, contracting seems to be a classical financing strategy of efficiency measures for energy conservation. However, it can also be held as sufficiency strategy due to the fact that on both sides, that of the owner of the building and that of the tenant, the structures of need satisfaction change through energy supply and consumption.

\section{Case study waste contracting}

Based on the experiences outlined above, further significant resource efficiency potentials on the basis of contracting models can be assumed, for these can offer efficiency strategies combined with sufficiency strategies. For example, it might be considered to transfer the principle of performance contracting from the energy sector to the waste sector, as the Kiel enterprise Innotec that was founded in 1996 tries to realize. The innovation targets at a „financial incentive

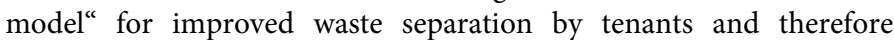
sustainable cost reductions in the operation of residential properties [23]. It aims at key similarities of waste and energy: technical gridbased infrastructures with high shares of sunken investments, relevant negative externalities and public regulation for consumption-based fees: Thus the business model is based on two different pillars:

The area "conventional waste management" consists of an intensive personal counselling of tenants regarding correct waste separation and prevention of waste in different languages with campaigns specific to target groups such as "There is space in the smallest kitchen". The focus of these activities, however, is on the visual inspection of residual waste bins which is conducted by personnel of Innotec a few times per week, the so-called property supervisors, and sorts out bulky and large volume waste such as cardboard boxes or other large packaging in order to achieve a reduction in residual waste amounts [23]. Even after intensive counselling, this task has to be performed repeatedly and regularly, as counselling alone does not lead to lasting changes in waste separation behaviour. Innotec hereby emphasizes that from the point of view of waste legislation this doesn't involve the sorting of waste in technical terms but simply a correction of filling mistakes. In doing so, neither a withdrawal of recyclable materials - all waste liable to collection for disposal are in fact left to local authority waste management services - nor waste compaction takes place. Besides this, the enterprise also grants a regular cleaning of the waste bin locations.

Moreover, Innotec offers technical systems for a "consumer-related waste management" as an extension of its offer, which enable an individual registration and accounting of residual waste amounts by means of "waste identification" systems. Waste locks are hereto 
installed in residual areas which outwardly hardly differ from normal standard washed concrete boxes but where waste can only be disposed with a transponder chip, while being weighed at the same time Alternatively, waste containers are installed which can be filled with either 51 or 201 waste sacks and only individually register the number of fillings. The individual attribution achieves that residents only have to pay for their individual amount of residual waste and therefore have a real incentive to save money on fees by optimized sorting and wasteconscious consumption.

Even if the approach of individual transponder chips is based on a technical innovation, it particularly bets on a behavioural change of tenants and therefore combines efficient technology with altered consumption patterns for the satisfaction of needs. Though the focal point of Innotec's services is the correction of filling mistakes directly at the waste location, an essential component of the concept is, according to Innotec, also the information of tenants and the development of a fundamental awareness of costs and saving potentials in the area of waste [24].This necessary knowledge transfer has to be adapted to the gradual alteration of collection infrastructure very carefully; among other things, tenants regularly have to be informed about purpose and success of individual measures (more "yellow bins", introduction of an organic waste bin, introduction of waste locks, restriction of filling volumes etc.) [24]. The involvement of tenants in the concept is of central significance, also in order to prevent economic incentives that lead to waste being disposed in the environment in order to save costs. Investigations of the Witzenhausen institute after the introduction of waste locks showed however, that through intensive counselling no increase in wild waste deposits was noticed and the cleanliness at waste locations even increased considerably. The institute states that "after the introduction of the locks, no increase in environmental pollution and no wild waste deposits or illegal disposal of waste occurred in the investigated area and its surroundings" [25]. Meanwhile the enterprise supervises about 250 housing companies with 630,000 housing units and 1.5 Million tenants throughout Germany [26]. Innotec concentrates its activities as far as possible on social or publicly promoted residential construction, where tenants often have no distinct awareness for waste separation or prevention due to language barriers, education level or social environments. In high-grade apartments, however, the situation is often met that inhabitants are quite willing to spend 300 Euros or more per year on waste fees if it grants them sufficiently high volumes of residual waste at any time and the level of incidental costs does not form the relevant criterion in the decision to rent [27].

\section{Contribution to sustainable resource management and reduction of resource consumption}

Scientifically accompanied evaluations of Innotec projects in Hamburg and Erfurt revealed that the introduction of a consumeroriented accounting of fees especially increased the amount of separately collected materials and therefore more materials could be directed to material recycling. This leads to a decrease in waste-related $\mathrm{CO} 2$ burdens of up to $60 \%$ [28].

In this way, the amount of collected packaging from the dual system in e.g. Erfurt could be increased by $60 \%$, while separately collected organic waste even increased by $400 \%$. Residual waste generation specific to inhabitants could hereby be reduced from $3.85 \mathrm{~kg}$ per week to $0.8 \mathrm{~kg}$ per week, see Figure 1[29].

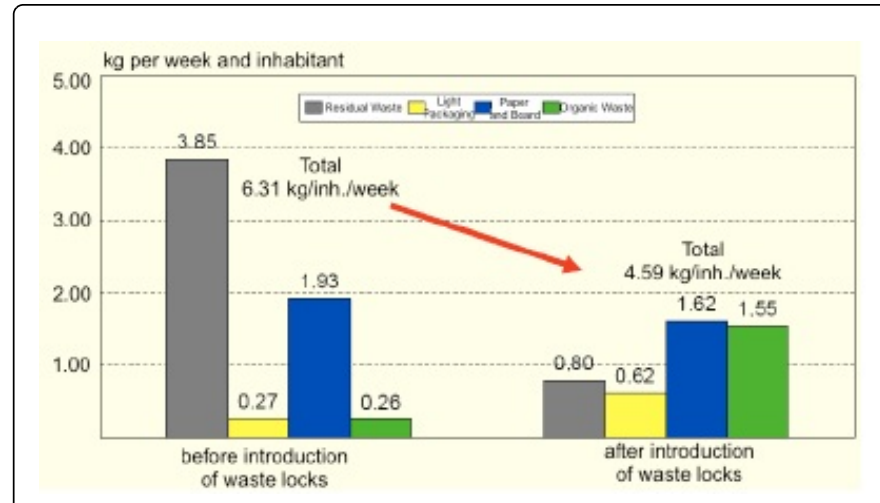

Figure 1: Changes in waste streams through the introduction of waste locks [29].

Taking a broader view on all recycling paths such as e.g. recycling depots, a residual amount of $800 \mathrm{~g}$ per inhabitant and weak results, which can either be effectively prevented or shifted, e.g. to waste disposal at work. The accompanying scientific study comes to the following conclusion: "The introduction of waste locks encouraged the affiliated inhabitants to realize the fundamental waste economic ideas of prevention and recycling in their disposal behaviour" [29].

\section{Triggers and required framework conditions of waste contracting}

Starting point and occasion for the introduction of a sufficiency strategy in the waste sector were particularly the dramatically increased waste fees in the 1990s that turned waste fees into an effectively relevant cost block of residential incidental costs. The monthly cost of waste disposal and street cleaning in Germany amount to approximately 0.17 Euros per square meter on average - thus highlighting the importance of framework conditions like landfill bans and specific technical treatment obligations in Germany, inter alia aiming at economic incentives for high quality waste recycling or waste prevention. Another important driver for innovation is the intensified competition on the housing market. In the face of the demographic development in Germany, homeowners and especially big housing associations can no longer expect to find tenants for their housing spaces at arbitrary prices. Therefore property owners try to secure the competitiveness of their renting objects by means of efficient facility management that aims at low incidental costs regarding, among others waste.

Sorting analyses have revealed that particularly in the area of social housing waste disposal is "especially inefficient" because of the widely anonymous collection in large bins, meaning that on the one hand waste is not correctly separated and on the other hand significant amounts of light packaging can still be found in residual waste subject to charges. Added to this is the specific situation that rent in these places is often entirely paid by the social security office, so that the level of waste fees offers no economic incentive to inhabitants. This also signifies that waste volumes, which usually represent a benchmark of cost calculation, are not considered sufficiently. A classical example for this isfor example the disposal of high-volume cardboard boxes or bulky waste through residual waste bins. „Anonymity effects and convenience" [27] lead to classical cost externalisations, caused by the individual conviction of every inhabitant that for example his disposal 
of bulky waste through the residual waste bin saves him the trip to the recycling depot or the commissioning of the large refuse disposal unit (which is often even free of charge) and therefore reduces his costs. Especially the large 1,1001 containers common in residential construction even enable e.g. the disposal of whole cupboards etc. through the residual waste bin. In these housing complexes it could be empirically observed that every offered waste volume has been used in the end; the amount of generated waste followed the available volume (up to a specific maximum limits of approximately 1801 per person and week - however, the differences would be clearly lower if real weight would be registered instead of volume). These different effects lead to the fact that residual waste amounts and corresponding charges in social housing were significantly higher, on average about 3-4 times, than the comparative figures for e.g. one-family-houses, which dispose about 301 of waste per week and person on average, whereby in this case the correlation between the level of charges and residual waste generation is clearly recognizable. In the face of these tremendous cost savings potentials, Innotec was able to grow very fast especially in congested areas with large numbers of social housing complexes.

\section{Business case and involved actors}

Waste Contracting has its business case through the cost savings with regard to residual waste disposal. For landlords the total costs of waste disposal in past projects, depending on waste economic framework conditions, decreased by $20-50 \%$, in individual cases by up to $70 \%$, due to subsequent sorting [26] - hence properties can be offered at competitive conditions on the market. Innotec is exclusively funded by a profit sharing of these saved costs. Usually a pilot phase of five years is arranged in projects, during which Innotec obtains $75 \%$ of the saved residual waste fees in order to refinance installation engineering and the initially personnel-intensive counselling of tenants. After this pilot phase, Innotec still receives $50 \%$ of the savings in case the project is continued. A conducive factor has proven to be the fact that the owner's expenditures for waste management services can be applied to the income tax as household-related services.

Advantages result also for tenants, as the emerging costs of the residential area are no longer calculated on a flat-rate basis per head or square meter, but according to the individual waste behaviour. According to surveys of the German Tenant's Association, $65 \%$ of all tenants wish for a more consumer-related calculations of running costs [28].Moreover, the optimized separated collection and the correction of filling mistakes altogether leads to a clear reduction in residual waste fees. Innotec argues that cities also benefit from optimized waste management: On average, $20 \%$ of the inhabitants of large residential complexes are welfare recipients, whose decreased rental charges lead to lower rental subsidies. Taking Duisburg as an example, savings in rental charges of 1.7 Million Euros would lead to municipal savings of 180,000 Euro [30].

\section{Conclusions}

The case study and the triggered political discussions show that on the one hand, sufficiency strategies are no longer a simply private question of individual consumer choices. Private consumer choices, sufficient or not sufficient, are always dependent on several impact factors and enabled or restricted by economic, political and infrastructural framework conditions. Due to existing incentives and offers it can be assumed that the increased implementation of more sufficient lifestyles can hardly be simply promoted by the demand side of the market. Due to the fact that the sole addressing of the consumer in order to implement more sufficient lifestyles constitutes an excessive demand [31], sufficient business strategies and offers are needed, just as directional political framework conditions promoting sufficiency.

On the other hand, initiatives like Innotec, which target at the prevention of waste as a component of their business model, show that sufficiency strategies as business cases can be successfully implementable. Innotec has by no means been initiated out of the normative idea of a low-waste economy, but because a lucrative business field was expected. Even the selection of projects doesn't occur from a perspective of maximum contribution to resource efficiency, but from the angle of maximum return. Nevertheless, the business model clearly contributes to more sufficient lifestyles which by now significantly influence the business interests of established waste management actors that have invested in waste management infrastructures - partly financed by fee payments.

Despite of relevant resource efficiency potentials, demands for national sufficiency politics have moral concerns, as they would intervene in fundamental rights and freedom of the individual in a particular manner and quality based on the (alleged) claim of renunciation. This, however, relates the concept of freedom solely to the freedom of the consumer and therefore strongly curtails it. In contrast, politics as facilitator of "positive freedom" (Thomas Green Hill) creates liberties for the development of individual ways of life without restricting the freedom of others [15].

In this way, every form of political framework setting (even the omission of such) always constitutes an influence on the possibilities and liberties of the individual. Therefore the reference to a restriction of the market doesn't release politics from the liability of creating suitable framework conditions that contribute to waste prevention and other sufficient lifestyles: "As little as politics alone can create sufficient lifestyles, as hard it is without them, according to our conviction" [9]. The German Advisory Council on Global Change (WBGU) justly refers to the necessity of a "shaping state with extended participation", that initiates "search processes" and directs them by means of frameworks and agenda setting [32].

\section{Instruments for the promotion of sufficient contracting models}

The basic approach of contracting raises the question to what extent the application of public resource political instruments is necessary at all: "Contracting as operation and financing model generally doesn't require separate promotion: In order to stay successful in the long run, contracting has to be economic per se" [33]. Especially with the herein chosen focus on the promotion of sufficient lifestyles, different starting points result for the promotion of contracting models and the overcoming of information deficits, high transaction costs due to lacking experience as well as path dependencies and bureaucratic procedures.

In Baden Wuerttemberg, the issues most relevant for the representatives of suppliers, consumers and financial management have been discussed and central recommendations were expressed in the framework of a contracting offensive. The focus was on contracting models in the area of energy; however, these approaches are also widely transferable to the area of resource efficiency:

Communications-initiative contracting: Especially in the area of resource efficiency, contracting possibilities are not yet sufficiently 
Page 5 of 6

known. This was addressed by a communications initiative that aimed to predominantly target at political decision-makers, to whom the potentials of such models are often not very familiar. As a further circle of addressees, the supporting partners for enterprises in the area of finances, especially accountants, tax consultants and banks, were addressed as the parties trusted by decision-makers in enterprises that could take on an important role as "contracting multipliers". For the topic of resource contracting, a lack of project developers and consultants exists which could support and counsel contracting customers as experienced, competent and neutral partners. The aim should be the qualification of engineers, planners, architects and actors of existing resource efficiency counselling institutions as project developers. A comparable lack exists on the supply side.

Extending financing options for contracting: If a contractor can offer financing to the client at the same time, his market position improves. Adapted financing models are particularly missing for small projects in conjunction with new and smaller contractors. Therefore the framework of the Baden-Wuerttemberg project recommended the development, testing and distribution of new financing models together with principal banks and the federation of cooperatives which are not directly oriented towards the credit standing of the contractor or its counterpart (e.g. project-based financing). Furthermore, successful contracting models require hedging instruments such as contingency insurance or indemnity bonds in order to minimise the risk for both the contracting client and the contractor.

\section{Possibilities of transmission}

With a view on the transmission of the contracting approach to the topic of waste prevention, the question arises for which further application fields contracting is feasible, or on which areas the support of sufficiency business models should focus. Figure 2 shows the distribution of the total resource consumption in Europe to different consumption areas. Against this background, an example would be to focus on the prevention of food waste, as significant economic and ecologic potentials could be generated here - food waste represents a significant share of residual waste, shows large prevention opportunities and at the same time massive resource conservation potentials $[34,35]$.

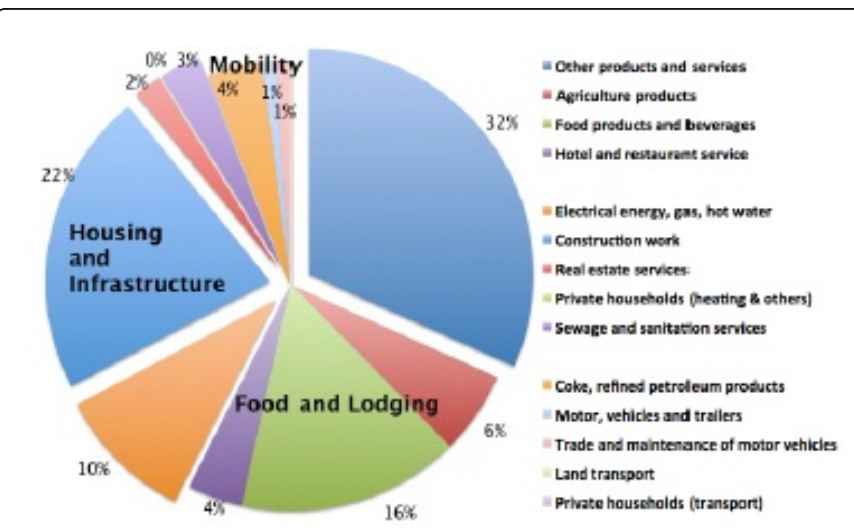

Figure 2: Absolute Resource Consumption (TMR) by Consumption Areas.

Fischer et al. [36], following Bilharz [37], refer to the criteria of ,radiating effect' and the potential for structural change in the selection of topics for sufficiency and contracting strategies. 'Radiating effect' means that a measure is so convincing that it is suitable to find imitators. The 'potential for structural change' describes a measure who changes the individual situation or the social practice in a way that the achieved environmental disburdening is most likely permanent [36]. Against this background, they recommend the use of cars, electricity saving, dietary shifts to Mediterranean food and living space reductions as interesting fields of action for sufficiency - though not all cases reveal how business models could be built upon these topics. Especially the topic of preventing food waste would be an important field of action for structural change due to its emotional charge and high radiating effect as well as its economic and ecological potentials.

\section{Further Research Questions}

The example of waste contracting shows that sufficiency can successfully function as business case and opens up business opportunities. However, existing concepts for sufficiency business strategies in business administration are only at the beginning stage: For an extended understanding of sufficiency-promoting business models, considerably extended knowledge about existing and prospectively possible sufficiency-based business models is required:

- What are success factors of existing business models, where have social trends for sufficiency successfully been adapted in the framework of innovative business ideas? How can these business models and their success factors be systematized? [21]. In which way is the specific extended producer responsibility scheme for waste packaging a necessary framework condition for such approaches?

- Who are relevant veto players whose traditional business models might be threatened by concepts of sufficiency and waste prevention, e.g. companies with large sunk costs in waste treatment facilities?

- Which sectors hold particular development potentials? How can traditional business models in these sectors be restructured in order to contribute to resource efficiency? [38].

\section{References}

1. Stengel O (2011) Suffizienz: Die Konsumgesellschaft in der ökologischen Krise. München

2. Linz M, Bartelmus P, Hennicke P, Jungkeit R, Sachs W, et al. (2002) Von nichts zuviel. Suffizienz gehört zur Zukunftsfähigkeit. Über ein Arbeitsvorhaben des Wuppertal Instituts. Wuppertal Institute for Climate, Environment, Energy, Germany .

3. Linz M (2012) Weder Mangel noch Übermaß: Warum Suffizienz unentbehrlich ist. München, Germany.

4. Paech N (2012) Befreiung vom Überfluss. Auf dem Weg in die Postwachstumsökonomie. München, Germany.

5. Bringezu S, Bleischwitz R (2009) Sustainable Resource Management. Trends, Visions and Policies for Europe and the World, Greenleaf Publisher, Sheffield, UK.

6. Madlener R, Alcott B (2011) Herausforderungen für eine technischökonomische Entkoppelung von Naturverbrauch und Wirtschaftswachstum unter besonderer Berücksichtigung der Systematisierung von Rebound-Effekten und Problemverschiebungen. Enquete-Commission 'Wachstum, Wohlstand, Lebensqualität' of the German Bundestag, Berlin, Geermany.

7. Hertwich EG (2005) Consumption and the Rebound Effect: An Industrial Ecology Perspective. Journal of Industrial Ecology 9: 85-98. 
Citation: Wilts H, Palzkill A (2015) Towards the Circular Economy: Waste Contracting. Int J Waste Resources 5: 174. doi:

Page 6 of 6

8. Jenkins J, Nordhaus T, Shellenberger M (2011) Energy Emergence. Rebound and Backfire as Emergent Phenomena. The Breakthrough Institute, CA, USA.

9. Heyen DA, Fischer C, Barth R, Brunn C, Grießhammer R, et al. (2013) Suffizienz: Notwendigkeit und Optionen politischer Gestaltung. ÖkoInstitut Working Paper, Germany.

10. Linz M (2002) Warum Suffizienz unentbehrlich ist. In: Von nichts zuviel. Suffizienz gehört zur Zukunftsfä- higkeit. Über ein Arbeitsvorhaben des Wuppertal Instituts; M. Linz et al. (Ed.) Wuppertal Institutefor Climate, Environment, Energy, Germany.

11. Linz M (2004) Weder Mangel noch Übermaß. Über Suffizienz und Suffizienzforschung. Wuppertal Institute for Climate, Environment, Energy, Germany.

12. Alcott B (2007) The sufficiency strategy: Would rich-world frugality lower environmental impact? Ecological Economics 64: 770-786.

13. Linz M (2006) Was wird dann aus der Wirtschaft? Über Suffizienz, Wirtschaftswachstum und Arbeitslosig- keit, Germany.

14. Paech N (2011) Vom grünen Wachstumsmythos zur Postwachstumsökonomie. In: Welzer, H./Wiegandt, K. (ed.)Perspektiven einer nachhaltigen Entwicklung, Frankfurt, Germany.

15. Schneidewind U, Zahrnt A (2013) Damit gutes Leben einfacher wird Perspektiven einer Suffizienzpolitik. Oekom Verlag, München, Germany.

16. Huber J (2000) Industrielle Ökologie. Konsistenz, Effizienz und Suffizienz in zyklusanalytischer Betrachtung. In: Simonis, Udo Ernst (ed): Global Change. Baden-Baden.

17. Sachs W (1993) Die vier E's: Merkposten für einen maß-vollen Wirtschaftsstil. Politische Ökologie 11: 33.

18. Paech N (2005) Nachhaltiges Wirtschaften jenseits von Innovationsorientierung und Wachstum $\mathrm{\bigotimes}$ : eineunternehmensbezogene Transformationstheorie. Marburg: Metropolis.

19. Reichel A, O’Neil D, Bastin C (2010) 'Enough Excess Profits: Rethinking Business'. In: O’Neill, D., Dietz, R., Jones, N. (Eds.) Enough is enough. Ideas for a sustainable economy in a world of finite resources: 87-94. Leeds: Center for the Advancement of the Steady State Economy (Arlington, Virginia, USA), 2010; Economic Justice for All (Leeds, UK).

20. Reichel A, Seeberg B (2011) The Ecological Allowance of Enterprise: An Absolute Measure of Corporate. Journal of Environmental Sustainability 1: $1-14$.

21. Sommer A (2012) Managing Green Business Model Transformations. Dissertation. Springer Verlag.

22. Schneidewind U, Palzkill A (2011) Nachhaltiges Ressourcenmanagement als Gegenstand einer transdisziplinären Betriebswirtschaftslehre Suffizienz als Business Case.In: Corsten, H., Roth, S. Nachhaltigkeit Unternehmerisches Handeln in globaler Verantwortung, Wiesbaden.
23. Innotec Abfallmanagement $\mathrm{GmbH}$ (n. d.) Referenzen. Ausgewählte Kunden im Konventionellen Abfallmanagement.

24. Innotec Abfallmanagement $\mathrm{GmbH}$ (2004)GWH setzt auf Abfallmanagement. Pilotprojekt in Bad Vilbe, Germany.

25. Witzenhausen-Institut (2007) Wissenschaftliche Begleitung der Einführung von Müllschleusen in der Stadt Erfurt. Final Report. Witzenhausen, Germany.

26. Innotec Abfallmanagement $\mathrm{GmbH}$ (2009) Der Innotec-Quotient. Modernes Abfallmanagement. Brochure.

27. Wilts H (2014) Nachhaltige Innovationsprozesse in der kommunalen Abfallwirtschaftspolitik - eine vergleichende Analyse zum Transition Management städtischer Infrastrukturen in deutschen Metropolregionen. Dissertation at the TU Darmstadt, Research group, Spatial and Infrastructure Planning, Darmstadt, Germany.

28. Hunklinger R (2011)Die intelligente Tonne. Innotec bietet modernes Abfallmanagement: Mülltonnen, deren Chip die Einwürfe zählt. Cleantech Magazin, Ausgabe.

29. Kern M (2007) Ergebnispräsentation von verursachergerechten Abfallmanagementsystemen im Wohnungsbau am Beispiel Müllschleusen in Erfurt. Practical forum. Witzenhausen, Germany.

30. Innotec Abfallmanagement $\mathrm{GmbH}$ (2011) Was leisten private Anbieter im Entsorgungs-Standortservice? Recycling Portal, Europe.

31. Grunwald A (2012) Against Privatisation of Sustainability - Why Consuming Ecologically Correct Products Will Not Save the Environment. GAIA - Ecological Perspectives for Science and Society 19: 178-182.

32. WBGU - Wissenschaftlicher Beirat der Bundesregierung Globale Umweltveränderungen (2011)Welt im Wandel - Gesellschaftsvertrag für eine Große Transformation; Berlin, Germany.

33. EnergieAgentur.NRW (2014) Förderprogramme \& Contracting.

34. FAO (2012) Global Food Losses and Food Waste. Interpack2011 Düsseldorf, Germany.

35. UNEP (2013) Food Waste Facts.

36. Fischer C, Grießhammer R (2013) Suffizienz: Begriff, Begründung und Potenziale. Working Paper, Öko-Institut, Germany.

37. Bilharz M (2008) "Key Points" nachhaltigen Konsums; Metropolis, Marburg, Germany.

38. Palzkill A (2012) Business model resilience in the context of corporate sustainability transformation. Conference Paper. The 18th Greening of Industry Network Conference, 2012: 22-24. 